\title{
natureouTLOOK TRADITIONAL ASIAN MEDICINE
}

22/29 December 2011 / Vol 480 / Issue No. 7378

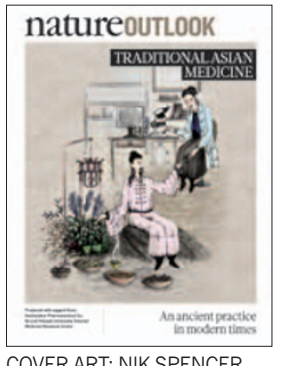

COVER ART: NIK SPENCER

\section{Editorial}

Herb Brody,

Michelle Grayson,

Tony Scully

Art \& Design

Wes Fernandes,

Alisdair MacDonald,

Andrea Duffy

Production

Karl Smart, Emilia

Orviss, Leonora

Dawson-Bowling

Sponsorship

Yvette Smith,

Yuki Fujiwara,

Gerard Preston

Marketing

Elena Woodstock,

Hannah Phipps

Project Manager

Helen Anthony

Art Director

Kelly Buckheit Krause

Magazine Editor

Tim Appenzeller

Editor-in-Chief

Philip Campbell

Editorial advisor

Felix Cheung
W hen the topic of traditional Asian medicine was first mooted, we were sceptical. To a magazine based in Europe and steeped in the history of science, there is much about traditional Asian medical practice that seems mystical and pseudoscientific. Other than well known success stories - artemisinin for malaria, and arsenic trioxide for leukaemia - there seemed to be a lack of scientifically proven remedies.

Yet a bit of probing revealed what a complex story this is. Not only are big efforts underway to modernize traditional medicine in China and Japan, but Western medicine is adopting some aspects of the Eastern point of view too. In particular, modern medical practitioners are coming around to the idea that certain illnesses cannot be reduced to one isolatable, treatable cause. Rather, a fall from good health often involves many small, subtle effects that create a system-wide imbalance.

But do traditional medicines actually work? Their personalized nature makes randomized controlled trials - the gold standard for testing drugs - extremely difficult. Rarely are two formulations identical. However, as modern medicine becomes more personalized, using biological and genetic markers, it is inadvertently developing the tools to better test traditional medicines.

Although artemisinin and arsenic trioxide are the archetypal examples of successful modern medicines mined from traditional Asian medicine, they do not represent the ideal convergence of the two systems. There are unique aspects to traditional Asian medicine that could hold great promise if they are artfully investigated. The goal of science should be to rigorously test each claim and sort the medical wheat from the pseudoscientific chaff.

We acknowledge the financial support of Saishunkan Pharmaceutical Co., ltd and Kitasato University Oriental Medicine Research Center in producing this Outlook. As always, Nature takes full responsibility for all editorial content.

\section{Michelle Grayson}

Associate Editor, Nature Outlooks.

\section{CONTENTS}

S82 TCM

Made in China

A persisting practice through the times

S84 CONVERGENCE

Where West meets East

Common objectives, but different ways

S87 PERSPECTIVE

All systems go

Jan van der Greef

S88 MICROBIOME

That healthy gut feeling

When medicine is your cup of tea

S9O MODERNIZATION

One step at a time

Applying scientific standards to TCM

S93 PATENTS

Protecting China's national treasure

Building a wall around property

S94 MODERN TCM

Enter the clinic

What's in store for today's patient?

S96 JAPAN

Will the sun set on Kampo?

A shadow is cast across the country

S97 PERSPECTIVE

Herbal danger

Masatomo Sakurai

S98 REGULATIONS

Herbal medicine rule book

Turning a new page in the West

\section{S100 PERSPECTIVE}

The clinical trial barriers

Liang Liu et al.

S101 BIODIVERSITY

Endangered and in demand

What's driving demand?

\section{COLLECTION}

\begin{tabular}{|c|c|}
\hline \multirow{6}{*}{$\begin{array}{l}\text { Nature Outlooks are sponsored supplements that aim to stimulate } \\
\text { interest and debate around a subject of interest to the sponsor, while } \\
\text { satisfying the editorial values of Nature and our readers' expecta- } \\
\text { tions. The boundaries of sponsor involvement are clearly delineated } \\
\text { in the Nature Outlook Editorial guidelines available at http://www. } \\
\text { nature.com/advertising/resources/pdf/outlook_guidelines.pdf }\end{array}$} & All featured articles will be freely available for 6 months. \\
\hline & SUBSCRIPTIONS AND CUSTOMER SERVICES \\
\hline & For UK/Europe (excluding Japan):Nature Publishing Group, \\
\hline & Subscriptions, Brunel Road, Basingstoke, Hants, RG21 6XS, UK. \\
\hline & Tel: +44 (0) 1256329242 . Subscriptions and customer services for \\
\hline & Americas - including Canada, Latin America and the Caribbean: \\
\hline CITING THE OUTLOOK & Nature Publishing Group, 75 Varick St, 9th floor, New York, NY \\
\hline Cite as a supplement to Nature, for example, Nature Vol XXX, & 10013-1917, USA. Tel: +18663637860 (US/Canada) or +1212726 \\
\hline No. XXXX Suppl, SxX-Sxx (2011). To cite previously published & 9223 (outside US/Canada). Japan/China/Korea:Nature Publishing \\
\hline articles from the collection, please use the original citation, which & Group - Asia-Pacific, Chiyoda Building 5-6th Floor, 2-37 Ichigaya \\
\hline can be found at the start of each article. & Tamachi, Shinjuku-ku, Tokyo, 162-0843, Japan. Tel: +8133267 8751. \\
\hline VISIT THE OUTLOOK ONLINE & CUSTOMER SERVICES \\
\hline e Nature Outlook Traditional Asian Medicine supplem & Feedback@nature.com \\
\hline ind at http://www.nature.com/nature/outlook/asian & Copyright $\odot 2011$ Nature Publishing Group \\
\hline
\end{tabular}

S105 The discovery of artemisinin (qinghaosu) and gifts from Chinese medicine Youyou Tu

S109 Adenosine A1 receptors mediate local anti-nociceptive effects of acupuncture Nanna Goldman et al.

S115 Steroid-like compounds in Chinese medicines promote blood circulation via inhibition of $\mathrm{Na}^{+} / \mathrm{K}^{+}$-ATPase Ronald J.Y. Chen et al. 